\title{
Impact of very short-lived halogens on stratospheric ozone abundance and UV radiation in a geo-engineered atmosphere
}

\author{
S. Tilmes ${ }^{1}$, D. E. Kinnison ${ }^{1}$, R. R. Garcia ${ }^{1}$, R. Salawitch ${ }^{2}$, T. Canty ${ }^{2}$, J. Lee-Taylor ${ }^{1}$, S. Madronich ${ }^{1}$, and K. Chance ${ }^{3}$ \\ ${ }^{1}$ National Center for Atmospheric Research, Boulder, Colorado, USA \\ ${ }^{2}$ University of Maryland College Park, MD, USA \\ ${ }^{3}$ Harvard-Smithsonian Center for Astrophysics, Cambridge, MA, USA
}

Correspondence to: S. Tilmes (tilmes@ucar.edu)

Received: 28 July 2012 - Published in Atmos. Chem. Phys. Discuss.: 27 August 2012

Revised: 7 November 2012 - Accepted: 9 November 2012 - Published: 20 November 2012

\begin{abstract}
The impact of very short-lived (VSL) halogenated source species on the ozone layer and surface erythemal ultraviolet radiation ( $\mathrm{UV}_{\mathrm{ERY}}$ ) is investigated in the context of geo-engineering of climate by stratospheric sulfur injection. For a projected 2040 model atmosphere, consideration of VSL halogens at their upper limit results in lower ozone columns and higher $\mathrm{UV}_{\mathrm{ERY}}$ due to geo-engineering for nearly all seasons and latitudes, with $\mathrm{UV}_{\mathrm{ERY}}$ rising by $12 \%$ and $6 \%$ in southern and northern high latitudes, respectively. When VSL halogen sources are neglected, future $\mathrm{UV}_{\mathrm{ERY}}$ increases due to declines in ozone column are nearly balanced by reductions of $U_{\mathrm{ERY}}$ due to scattering by the higher stratospheric aerosol burden in mid-latitudes. Consideration of VSL sources at their upper limit tips the balance, resulting in annual average increases in $\mathrm{UV}_{\mathrm{ERY}}$ of up to $5 \%$ in mid and high latitudes. Therefore, VSL halogens should be considered in models that assess the impact of stratospheric sulfur injections on the ozone layer.
\end{abstract}

\section{Introduction}

A widely discussed geo-engineering approach considers the continuous injection of sulfuric acid particles into the tropical stratosphere, which results in an enhancement of the global sulfate aerosol layer in the stratosphere (e.g., Crutzen, 2006; Wigley, 2006; Rasch et al., 2008a,b; Tilmes et al., 2009). The resulting reduction of short-wave radiation due to geoengineering is expected to lower global temperatures, as observed after major volcanic eruptions (Solomon et al., 2007).
Observations obtained following the eruption of Mt. Pinatubo in June 1991 provide a basis for evaluating the environmental effects of stratospheric sulfur injection. Global cooling of about $0.5 \mathrm{~K}$ occurred after this eruption (Soden et al., 2002; Solomon et al., 2007), along with changes in precipitation patterns (Trenberth and Dai, 2007). In addition, a significant decrease of total column ozone was observed in mid- and high latitudes within a year after the eruption (Fahey et al., 1993; Solomon et al., 1996; Portmann et al., 1996; Tabazadeh et al., 2002). Increased ozone depletion is caused by faster rates of heterogeneous (surface mediated) chemical reactions on stratospheric liquid sulfate aerosols, supplied by the volcanic eruption. These reactions suppress the concentration of nitrogen oxides $\left(\mathrm{NO}_{\mathrm{x}}\right)$ and enhance the abundance of chlorine monoxide $(\mathrm{ClO})$ and hydroperoxyl $\left(\mathrm{HO}_{2}\right)$ (Fahey et al., 1993; Wennberg et al., 1994; Solomon et al., 1996).

The stabilization of surface temperatures by geoengineering would require a continuous injection of sulfur into the stratosphere to maintain a volcanic-like aerosol layer. Such a permanent stratospheric aerosol layer could bring about numerous other potential effects, such as a shift in the Asian and African monsoons (e.g., Robock et al., 2008). Our focus is on the quantification of the perturbation to the ozone layer and the amount of ultraviolet (UV) radiation reaching the surface in response to stratospheric sulfur injections.

Prior studies have shown that a persistent stratospheric aerosol layer can have a positive or negative impact on the abundance of ozone, depending on altitude, latitude, time of the year, and the amount of halogens in the stratosphere. In the polar region during spring (austral spring for the Southern 
Hemisphere (SH)), ozone loss rates are projected to increase significantly due to geo-engineering, as a result of increased efficiency of ozone loss by halogen cycles. A delay in the recovery of the Antarctic ozone hole of 40 to $70 \mathrm{yr}$ due to geoengineering was estimated, as well as a significant increase in the amount of ozone depletion at high northern latitudes through the end the 21st century, compared to background stratospheric aerosol conditions (Tilmes et al., 2008). For mid-latitudes, a decrease in the efficiency of ozone loss by the $\mathrm{NO}_{\mathrm{x}}$ cycle at around $25 \mathrm{~km}$ altitude results in an increase of ozone, whereas increased $\mathrm{ClO}_{\mathrm{x}}$ and $\mathrm{HO}_{\mathrm{x}}$ in the lower stratosphere reduce ozone (Tilmes et al., 2009; Heckendorn et al., 2009). The net effect of geo-engineering on column ozone was estimated to range between $-5 \%$ (Heckendorn et al., 2009) and $+3 \%$ (Tilmes et al., 2009) for low latitudes. A large reduction of column ozone between 10-15\% was calculated in these studies for high latitudes. Dynamical changes also influence the response of stratospheric ozone to geo-engineering (e.g., Stenchikov et al., 2002; Tilmes et al., 2009).

With the decline of stratospheric halogens (chlorine and bromine) driven by continued adherence to the Montreal Protocol, the ozone layer is expected to recover by the end of the century. Column ozone values are expected to exceed pre-1980 values, due to the increase in the strength of the Brewer-Dobson circulation driven by rising levels of greenhouse gases (Oman et al., 2010; Eyring et al., 2010). The impact of geo-engineering on ozone by mid-century is thought to be moderate, because halogen levels will be lower and column ozone may rise due to this circulation change. However, prior model studies that investigated the sensitivity of ozone to sulfate geo-engineering only considered the supply of stratospheric halogens from the decomposition of longlived organic source gases (Tilmes et al., 2009; Heckendorn et al., 2009).

The additional supply from very short-lived (VSL) bromocarbons has been suggested to have a significant impact in a volcanic-like stratospheric aerosol layer (Salawitch et al., 2005; Feng et al., 2007). The largest contribution to $\mathrm{Br}_{\mathrm{y}}$ from VSL bromocarbons is likely due to dibromomethane $\left(\mathrm{CH}_{2} \mathrm{Br}_{2}\right)$ and bromoform $\left(\mathrm{CHBr}_{3}\right)$. These species are produced by biogenic processes in the ocean (e.g., Quack and Wallace, 2003). The contribution of VSL bromocarbons to the total stratospheric inorganic bromine $\left(\mathrm{Br}_{\mathrm{y}}^{\mathrm{VSL}}\right.$ ) is estimated to range between 1 and $8 \mathrm{ppt}$ (WMO, 2010, Tables 1-14) with an upper limit of $10 \mathrm{ppt}$. The need for a significant contribution to stratospheric bromine from VSL bromocarbons is also supported by the recent study of Choi et al. (2012). Chlorine-containing VSL source gases have both anthropogenic and natural sources (WMO, 2010, Chapter 1, Sect. 1.3.1.1). Anthropogenic sources likely have largest contributions from dichloromethane $\left(\mathrm{CH}_{2} \mathrm{Cl}_{2}\right)$ and tetrachloroethene $\left(\mathrm{CCl}_{2} \mathrm{CCl}_{2}\right)$ from a variety of applications. Anthropogenic sources constitute about two thirds of the total stratospheric inorganic chlorine source from VSL species
$\left(\mathrm{Cl}_{\mathrm{y}}^{\mathrm{VSL}}\right)$ for present day conditions. The natural source is dominated by bromochloromethane compounds produced by oceanic, biogenic processes. The value for $\mathrm{Cl}_{\mathrm{y}}^{\mathrm{VSL}}$ is estimated to range between 25 and $170 \mathrm{ppt}$ (WMO, 2010, Tables 1-9).

Most models underestimate the amount of ozone depletion observed following the eruption of Mt. Pinatubo. Salawitch et al. (2005) showed this discrepancy could be resolved if stratospheric halogens from the decomposition of VSL bromocarbons were considered. Levels of bromine monoxide $(\mathrm{BrO})$ are enhanced in the lower stratosphere at all times compared to a model that neglects VSL bromocarbons. During periods of enhanced volcanic aerosol loading, $\mathrm{ClO}$ in the lower stratosphere is highly enhanced; this $\mathrm{ClO}$ then reacts with $\mathrm{BrO}$ from VSL sources, providing an efficient means for removal of stratospheric ozone (Salawitch et al., 2005). The consideration of VSL halogens is therefore expected to be important for geo-engineering studies given the large enhancement to the sulfate aerosol layer that would occur.

Our paper focuses on a case study that quantifies the importance of stratospheric $\mathrm{Br}_{\mathrm{y}}$ and $\mathrm{Cl}_{\mathrm{y}}$ from VSL source species for a hypothetical future geo-engineered environment. Chemical conditions for year 2040 are used, since this is about the time geo-engineering could potentially be applied. Furthermore, the role of VSL halogen species is expected to gain importance in the coming years, as stratospheric $\mathrm{Br}_{\mathrm{y}}$ and $\mathrm{Cl}_{\mathrm{y}}$ from long-lived sources decline due to the Montreal Protocol. The transport of halogen containing VSL gases to the stratosphere might also rise in the future, due to increases in tropical deep convection and alteration of the oxidation capacity of the troposphere driven by climate change (Hossaini et al., 2012). Year 2040 represents a period when anthropogenic $\mathrm{Br}_{\mathrm{y}}$ and $\mathrm{Cl}_{\mathrm{y}}$ are in decline, but have not yet reached background levels (Fig. 5-3, Eyring et al., 2010). Finally, changes in column ozone and aerosol are related to surface UV radiation, which has implications for human health and the well-being of the entire ecosystem. In Sect. 2, we describe the experimental design of the simulations used. Section 3 discusses changes in ozone abundances due to geo-engineering. In Sect. 4, we investigate changes in UV radiation resulting from geo-engineering under fixed dynamical conditions, using a radiative transfer model.

\section{Experiemental design}

The Whole Atmosphere Community Climate Model (WACCM) Version 3548 (Garcia et al., 2007) is used to investigate the impact of geo-engineering on ozone. WACCM is a global model with 66 vertical levels from the ground to $4.5 \times 10^{-6} \mathrm{hPa}$ (approximately $140 \mathrm{~km}$ geometric height). The vertical resolution is variable: $3.5 \mathrm{~km}$ above $65 \mathrm{~km}, 1.75 \mathrm{~km}$ around the stratopause $(50 \mathrm{~km}), 1.1-1.4 \mathrm{~km}$ in the lower stratosphere (below $30 \mathrm{~km}$ ), and $1.1 \mathrm{~km}$ in the troposphere (except near the ground where much higher vertical resolution is used in the planetary boundary layer). The 
horizontal resolution is $1.9^{\circ} \times 2.5^{\circ}$ (latitude $\times$ longitude). The chemical module is based upon the 3-D chemical transport Model of OZone and Related Tracers (MOZART), Version 3 (Kinnison et al., 2007). WACCM includes a detailed representation of the chemical and physical processes in the troposphere through the lower thermosphere (Garcia et al., 2007). The performance of WACCM has been evaluated within the CCMVal-2 framework, showing reasonably good agreement with observations important for model representation of transport, photochemistry, Upper Troposphere Lower Stratosphere (UTLS) processes, and polar ozone loss (Eyring et al., 2010). To investigate the chemical response of varying halogen levels in the stratosphere, the same meteorological fields are prescribed in several one-year simulations. Therefore, the impact of dynamical differences between geo-engineering and baseline simulations (as discussed in Tilmes et al., 2009), or the effect of dynamical feedbacks induced by VSL halogens, is not quantified.

We select meteorological conditions and surface area densities (SAD) of sulfuric acid aerosols of one year (year 2040) from a geo-engineering simulation performed for the period 2020-2050 by Tilmes et al. (2009). In that study, a fixed amount of injected sulfur dioxide $\left(\mathrm{SO}_{2}\right)$ was considered. The sulfate distribution was taken from Rasch et al. (2008b), who considered an injection of $2 \mathrm{TgS} \mathrm{yr}^{-1}$ of volcanic-sized aerosols into a $2 \mathrm{~km}$ thick layer at $25 \mathrm{~km}$ altitude in the tropics, between $10^{\circ} \mathrm{N}$ and $10^{\circ} \mathrm{S}$. The prescribed model meteorology used in all simulations is comparable to ozone loss conditions of a recently observed moderately cold Arctic polar vortex between January and March, considering the averaged potential for activated chlorine ( $\mathrm{PACl})$, as introduced by Tilmes et al. (2007). However, the Arctic polar vortex persists too long into April compared to recently observed conditions. A larger $\mathrm{PACl}$ in comparison to observations might result in an overestimation of chemical ozone loss in the Arctic polar vortex in April in northern high latitudes (see Supplement and Fig. S1 for further details).

The prescribed temperatures over Antarctica are slightly lower than recently observed and stay cooler into December compared to observations. Therefore, we also expect an overestimation of ozone loss in November and December compared to observed Antarctic conditions in recent years. These conditions might be reasonable for the geo-engineering simulations, assuming a potentially stronger and colder polar vortex (Tilmes et al., 2009). A potential overestimation of chemical ozone loss in northern and southern high latitudes in late spring is expected to have little impact on chemical changes in low and mid-latitudes due to geo-engineering and VSL species in this study.

We show results for chemical conditions of the stratosphere representative of years 2000 and 2040 following the CCMVal-2 definition (Eyring et al., 2006), including various assumptions regarding the amount of stratospheric $\mathrm{Br}_{\mathrm{y}}$ and $\mathrm{Cl}_{\mathrm{y}}$ from VSL source gas species $\left(\mathrm{Br}_{\mathrm{y}}^{\mathrm{VSL}}\right.$ and $\left.\mathrm{Cl}_{\mathrm{y}}^{\mathrm{VSL}}\right)$.
The year 2000 simulation is used to represent the contemporary atmosphere, for comparison to satellite observations of $\mathrm{BrO}$. The 2040 simulation is used to assess the impact of geoengineering on ozone and surface UV. Simulations are performed for three scenarios that differ in the amount of $\mathrm{Br}_{\mathrm{y}}^{\mathrm{VSL}}$ and $\mathrm{Cl}_{\mathrm{y}}^{\mathrm{VSL}}$. In the first case, denoted $\mathrm{VSL}=0$, bromine and chlorine enter the stratosphere only from long-lived halocarbons. This is the common condition for most model simulations within CCMVal-2 (Eyring et al., 2010). For the second case, denoted VSL $=6$, we artificially increase stratospheric $\mathrm{Br}_{\mathrm{y}}$ by $6 \mathrm{ppt}$ throughout the stratosphere. The stratosphere is defined by the $100 \mathrm{ppb}$ ozone isopleth, which represents the chemical tropopause. For the third case, we increase stratospheric $\mathrm{Br}_{\mathrm{y}}$ by $10 \mathrm{ppt}$ and $\mathrm{Cl}_{\mathrm{y}}$ by $100 \mathrm{ppt}$, denoted as VSL $=10+100$. The last case is meant to describe the upper limit of stratospheric halogen abundance from VSL sources. For all these cases, both baseline simulations (background $\mathrm{SAD}$ ) and geo-engineering simulations (enhanced $\mathrm{SAD}$ ) were performed. A detailed justification for the three different cases is based on previous literature and is discussed in the Supplement.

We further justify the use of values of 6 and $10 \mathrm{ppt}$ for $\mathrm{Br}_{\mathrm{y}}^{\mathrm{VSL}}$ by comparing WACCM BrO for chemical conditions in year 2000 to GOME total column BrO measured in April and October 1997 (Chance, 1998), as shown in Fig. 1. The left hand side of this figure compares total column $\mathrm{BrO}$ from GOME to stratospheric column BrO from WACCM. The difference between GOME and WACCM BrO shown in these panels is much larger than the change in $\mathrm{Br}_{\mathrm{y}}$ from 1997 to 2000 due to halogen sources (e.g., Eyring et al., 2010, Fig. 121).

The right hand panels of Fig. 1 illustrate the sensitivity of the comparison to tropospheric $\mathrm{BrO}$ and stratospheric $\mathrm{Br}_{\mathrm{y}}^{\mathrm{VSL}}$, neither of which is particularly well known. GOME BrO has been adjusted to represent only the amount of $\mathrm{BrO}$ present in the stratosphere, as a function of the assumed tropospheric BrO burden (red lines). This adjustment, described by Salawitch et al. (2005), is also outlined in the Supplement. The black lines show WACCM stratospheric column $\mathrm{BrO}$ assuming different values for $\mathrm{Br}_{\mathrm{y}}^{\mathrm{VSL}}$.

The best agreement between WACCM BrO and adjusted GOME $\mathrm{BrO}$ is found assuming a tropospheric $\mathrm{BrO}$ abundance of $1 \mathrm{ppt}$ and $\mathrm{Br}_{\mathrm{y}}^{\mathrm{VSL}}$ between 6 to $10 \mathrm{ppt}$ (Fig. 1, right panels). The very high levels of BrO observed by GOME at high latitudes during April 1997 are due to the spring-time Arctic bromine explosion, as described by Chance (1998). We make no attempt to model high tropospheric $\mathrm{BrO}$ associated with this event because the surface release of $\mathrm{BrO}$ has no bearing on our geo-engineering study. All latitudes for April are shown in Fig. 1 for completeness. However, the justification of 6 to $10 \mathrm{ppt}$ for $\mathrm{Br}_{\mathrm{y}}^{\mathrm{VSL}}$ is based on comparisons between GOME and WACCM for latitudes south of $50^{\circ} \mathrm{N}$ in April and for all latitudes in October. 

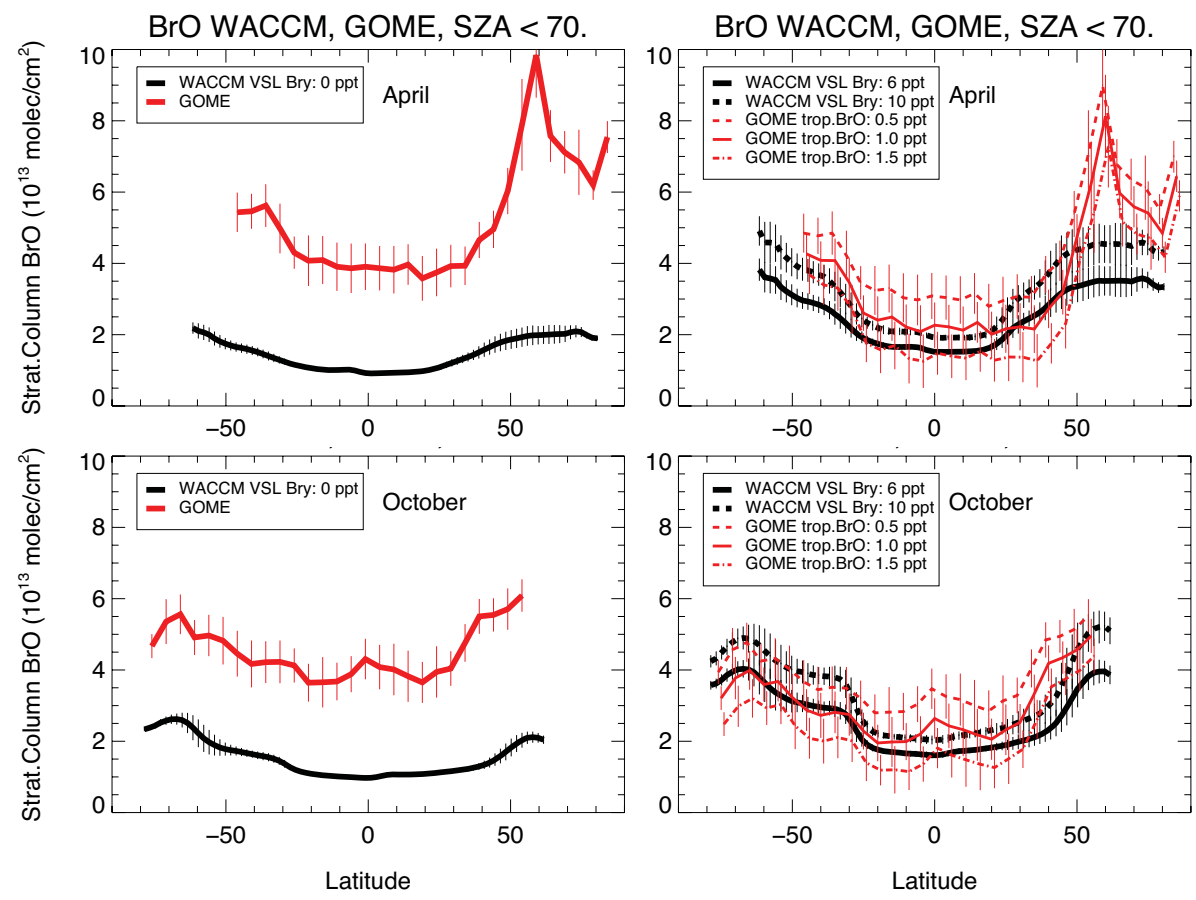

Fig. 1. Left panels: comparison of zonal average of total column BrO from GOME satellite observations in 1997 (Chance, 1998) (red lines) to WACCM stratospheric column BrO (black lines) for the year 2000. Right panels: inferred stratospheric column BrO from GOME total column adjusted for the presence of various amounts of tropospheric BrO (see text) (red lines, see legend) and zonal average of WACCM stratospheric $\mathrm{BrO}$ column, assuming different levels of $\mathrm{Br}_{\mathrm{y}}^{\mathrm{VSL}}$ (black lines; see legend). Top panels are for April and bottom panels for October. Error bars on all curves reflect the longitudinal variability (standard deviation about the zonal, monthly mean). WACCM BrO is for 10:30 a.m., the equator crossing time of GOME.

\section{Changes in ozone abundance}

The effect of geo-engineering on ozone, derived using the WACCM runs described above, is shown in Fig. 2, and Table 1 . Figure 2 shows the relative difference between model ozone in year 2040 for two runs of WACCM, one with enhanced stratospheric sulfur and another with background levels of stratospheric sulfur. Numerical values of absolute and relative differences are given in Table S1. Negative values indicate reductions of column ozone due to geo-engineering. Results are shown in Fig. 2 as a function of equivalent latitude (defined to follow isopleths of constant potential vorticity (PV)), which allows various dynamical regimes to be readily apparent.

For the VSL $=0$ simulation, geo-engineering causes column ozone in the polar vortex (60 to $90^{\circ}$ equivalent latitudes) for year 2040 to decrease by $8 \%$ for the Northern Hemisphere (NH) on average for the three months February, March, and April (FMA) and $10.5 \%$ for the SH averaging August, September, and October (ASO). These depletions rise to $10 \%$ and $13.5 \%$ for the $\mathrm{Br}_{\mathrm{y}}^{\mathrm{VSL}}=10 \mathrm{ppt}$, $\mathrm{Cl}_{\mathrm{y}}^{\mathrm{VSL}}=100 \mathrm{ppt}$ case. The influence of geo-engineering on $\mathrm{NH}$ polar ozone reported here is larger in all cases than that discussed by Tilmes et al. (2009). In contrast to earlier studies, where vortex temperatures between 2020-2050 are on average biased high in the $\mathrm{NH}$, we simulate conditions for a longer-lasting moderately cold Arctic polar vortex. In high latitudes in Southern Hemisphere (SH) summer (November, December, and January: NDJ), the relative difference in ozone between geo-engineering and baseline simulation for the VSL $=10+100$ case is smaller than the difference for the $\mathrm{VSL}=0$ case. The additional halogen loading for the $\mathrm{VSL}=10+100$ geo-engineering case causes ozone loss to reach very small values in the lower stratosphere in the longlasting Antarctic vortex in November and December and additional ozone depletion due to increased aerosols is limited, which is not the case for the VSL $=0$ and VSL $=6$ simulations.

In mid- and low latitudes, the VSL $=0$ simulation results in ozone changes due to geo-engineering that are small and for some latitudes and seasons positive: i.e., in some instances, geo-engineering leads to more ozone. However, when VSL halogens are considered, geo-engineering is found to decrease column ozone at almost all latitudes and for nearly all seasons. For instance, a $0.65 \%$ increase in column ozone is computed for 30 to $60^{\circ} \mathrm{N}$ during ASO in year 2040 if $\mathrm{VSL}=0$; the $\mathrm{Br}_{\mathrm{y}}^{\mathrm{VSL}}=10 \mathrm{ppt}$ and $\mathrm{Cl}_{\mathrm{y}}^{\mathrm{VSL}}=100 \mathrm{ppt}$ case leads to a $1.5 \%$ decrease in column ozone for this time and location. Further, in northern mid-latitudes in summer (May, June, and July: MJJ), the decrease of column 

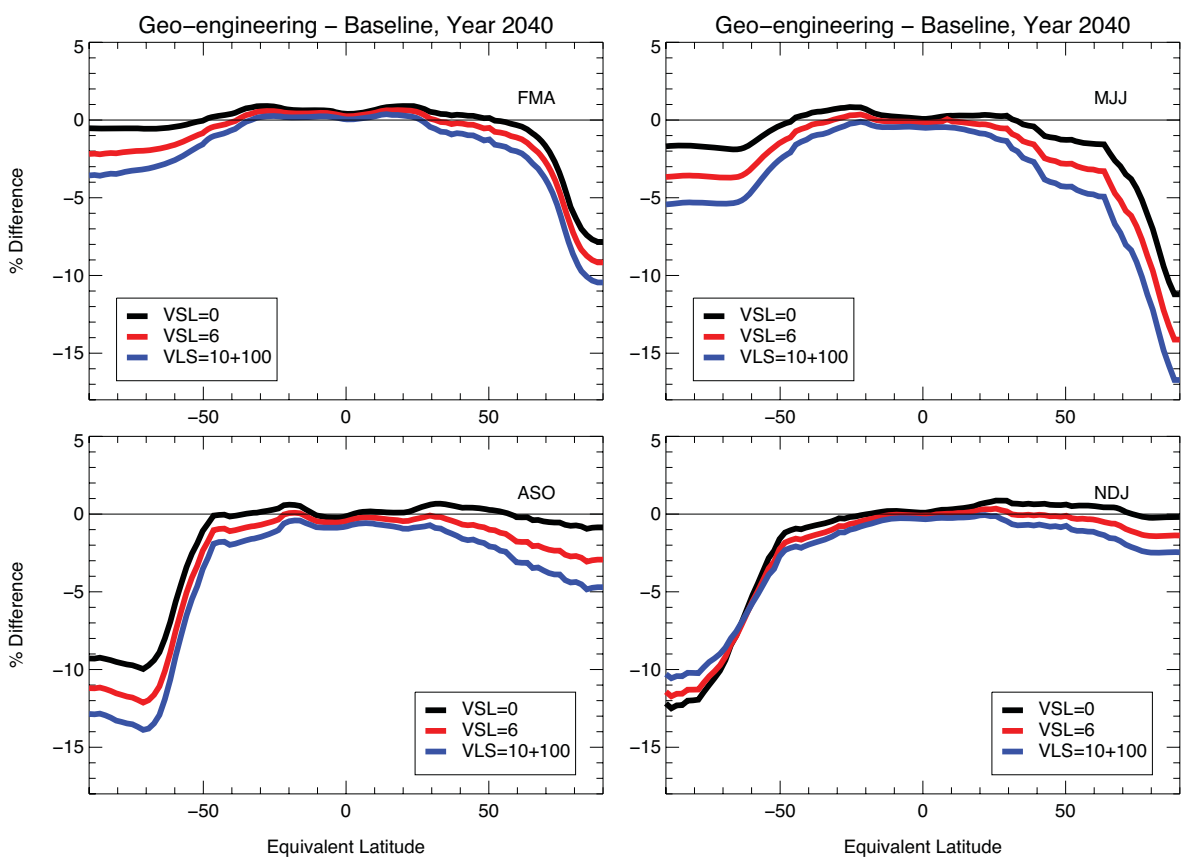

Fig. 2. Relative difference of column ozone between geo-engineering and baseline model results for four seasons (different panels). All calculations are for year 2040. Different values of VSL halogens are considered: $\mathrm{Br}_{\mathrm{y}}^{\mathrm{VSL}}$ and $\mathrm{Cl}_{\mathrm{y}}^{\mathrm{VSL}}$ both $=0(\mathrm{black}), \mathrm{Br}_{\mathrm{y}}^{\mathrm{VSL}}=6 \mathrm{ppt}$ and $\mathrm{Cl}_{\mathrm{y}}^{\mathrm{VSL}}=0$ (red), and $\mathrm{Br}_{\mathrm{y}}^{\mathrm{VSL}}=10 \mathrm{ppt}$ and $\mathrm{Cl}_{\mathrm{y}}^{\mathrm{VSL}}=100 \mathrm{ppt}$ (blue). Results are shown as a function of equivalent latitude.

ozone due to geo-engineering is doubled (from approximately $1.5 \%$ to $4 \%$ ) for $\mathrm{Br}_{\mathrm{y}}^{\mathrm{VSL}}=10 \mathrm{ppt}$ and $\mathrm{Cl}_{\mathrm{y}}^{\mathrm{VSL}}=100 \mathrm{ppt}$ in comparison to $\mathrm{VSL}=0$.

With increasing levels of stratospheric $\mathrm{Br}_{\mathrm{y}}^{\mathrm{VSL}}, \mathrm{BrO}_{\mathrm{x}}$ and $\mathrm{ClO}_{\mathrm{x}}$ ozone loss rates gain more importance in mid- and high latitudes (see Supplement and Fig. S2 for further details). The increase of ozone loss rates is especially apparent in the lower stratosphere in high polar latitudes in spring, where the $\mathrm{BrO}_{\mathrm{x}}+\mathrm{ClO}_{\mathrm{x}}$ ozone loss cycle dominates. $\mathrm{BrO}_{\mathrm{x}}+\mathrm{ClO}_{\mathrm{x}}$ loss rates double if geo-engineering aerosols are considered. Additional stratospheric $\mathrm{Br}_{\mathrm{y}}^{\mathrm{VSL}}$ of $10 \mathrm{ppt}$ and $\mathrm{Cl}_{\mathrm{y}}^{\mathrm{VSL}}$ of $100 \mathrm{ppt}$ result in about 3 times larger ozone loss rates compared to a baseline simulation between 10 and $15 \mathrm{~km}$. An appreciable impact of enhanced $\mathrm{Br}_{\mathrm{y}}$ is also found in mid-latitudes in summer, a time when the ozone column is smallest. Enhanced heterogeneous reactions amplify the $\mathrm{HO}_{\mathrm{x}}, \mathrm{BrO}_{\mathrm{x}}$ and $\mathrm{ClO}_{\mathrm{x}}$ cycles in the lower stratosphere whereas $\mathrm{NO}_{\mathrm{x}}$ ozone rates stay constant for different VSL cases. The most important cycle in summer mid- and high latitudes is the $\mathrm{HO}_{\mathrm{x}}$ cycle. The influence of geo-engineering on $\mathrm{HO}_{\mathrm{x}}$ ozone loss rates increases by about $75 \%$ if $\mathrm{Br}_{\mathrm{y}}^{\mathrm{VSL}}$ is assumed to be $6 \mathrm{ppt}$ or larger compared to $\mathrm{VSL}=0$ at around $12 \mathrm{~km}$ in northern high latitudes.

\section{Changes in UV radiation}

Decreasing column ozone as a result of enhanced stratospheric sulfate aerosols increases the amount of UV radia- tion reaching Earth's surface (e.g., Micheletti et al., 2003), which can harm human health by leading to skin cancer and eye damage. Increased UV can also harm terrestrial and aquatic ecosystems (UNEP, 2005). On the other hand, increased scattering by stratospheric sulfate aerosols can alter the radiation path lengths, increasing the diffuse-to-direct ratio of surface UV (Zeng et al., 1994). A large burden of sulfate aerosols due to geo-engineering, everything else being equal, can reduce the amount of incoming UV radiation due to enhanced scattering. A decrease in the production of tropospheric $\mathrm{O}\left({ }^{1} \mathrm{D}\right)$ by $\mathrm{O}_{3}$ photolysis, due to attenuation of actinic flux in the $290-330 \mathrm{~nm}$ wavelength region by stratospheric aerosol, led to a drop in modeled $\mathrm{OH}$ and an observed increase of $\mathrm{CH}_{4}$ and $\mathrm{CO}$ within 6 months after the Mt. Pinatubo volcanic eruption (Dlugokencky et al., 1996). A rise of the diffuse-to-direct ratio of surface UV following Pinatubo may have increased canopy photosynthesis and the land carbon sink (Mercado et al., 2009).

The radiative transfer model TUV (Tropospheric Ultraviolet and Visible) (Madronich and Flocke, 1997) is used to calculate surface UV radiation for all the simulations described above. The model calculates spectral irradiances from the simulated column ozone values over full diurnal cycles for each day of the year to capture the influence of changing solar zenith angle. Model irradiance is converted to monthly means, following the method of Lee-Taylor et al. (2010). Irradiance is then multiplied by the human erythema (skinreddening) spectrum (McKinlay and Diffey, 1987) (also used 
Table 1. Absolute and relative (in brackets) changes of column ozone in DU (\%), between geo-engineering and baseline model simulations for varying stratospheric bromine from VSL species for the year 2000 and 2040, averaged for different latitude bands and for different seasons.

\begin{tabular}{|c|c|c|c|c|c|}
\hline Season & Region & Year & $\mathrm{VSL}=0$ & $\mathrm{VSL}=6$ & $+\mathrm{Cl}_{\mathrm{y}}=100$ \\
\hline \multirow{8}{*}{ ANN } & \multirow[t]{2}{*}{$60-90^{\circ} \mathrm{N}$} & 2000 & $-15.89(-4.46)$ & $-21.94(-6.26)$ & $-27.03(-7.83)$ \\
\hline & & 2040 & $-9.74(-2.52)$ & $-15.57(-4.08)$ & $-20.59(-5.48)$ \\
\hline & \multirow[t]{2}{*}{$30-60^{\circ} \mathrm{N}$} & 2000 & $-4.48(-1.35)$ & $-8.26(-2.52)$ & $-11.71(-3.61)$ \\
\hline & & 2040 & $0.00(0.00)$ & $-3.32(-0.97)$ & $-6.41(-1.89)$ \\
\hline & \multirow[t]{2}{*}{$30-60^{\circ} \mathrm{S}$} & 2000 & $-7.30(-2.48)$ & $-10.25(-3.54)$ & $-12.67(-4.45)$ \\
\hline & & 2040 & $-3.15(-1.02)$ & $-5.90(-1.93)$ & $-8.19(-2.72)$ \\
\hline & \multirow[t]{2}{*}{$60-90^{\circ} \mathrm{S}$} & 2000 & $-14.24(-5.74)$ & $-16.73(-6.96)$ & $-18.47(-7.91)$ \\
\hline & & 2040 & $-13.82(-4.83)$ & $-16.42(-5.93)$ & $-18.15(-6.77)$ \\
\hline \multirow[t]{8}{*}{ FMA } & \multirow[t]{2}{*}{$60-90^{\circ} \mathrm{N}$} & 2000 & $-31.37(-8.47)$ & $-37.16(-10.26)$ & $-42.19(-11.93)$ \\
\hline & & 2040 & $-24.44(-5.79)$ & $-30.75(-7.43)$ & $-36.71(-9.07)$ \\
\hline & \multirow{2}{*}{$30-60^{\circ} \mathrm{N}$} & 2000 & $-6.03(-1.65)$ & $-10.27(-2.84)$ & $-14.64(-4.09)$ \\
\hline & & 2040 & $-1.20(-0.31)$ & $-4.86(-1.28)$ & $-8.81(-2.34)$ \\
\hline & \multirow[t]{2}{*}{$30-60^{\circ} \mathrm{S}$} & 2000 & $-3.18(-1.13)$ & $-6.16(-2.21)$ & $-8.80(-3.19)$ \\
\hline & & 2040 & $-0.15(-0.05)$ & $-2.74(-0.94)$ & $-5.01(-1.74)$ \\
\hline & \multirow[t]{2}{*}{$60-90^{\circ} \mathrm{S}$} & 2000 & $-7.33(-2.63)$ & $-13.12(-4.78)$ & $-17.83(-6.59)$ \\
\hline & & 2040 & $-2.79(-0.93)$ & $-7.70(-2.62)$ & $-11.77(-4.05)$ \\
\hline \multirow[t]{8}{*}{ MJJ } & \multirow[t]{2}{*}{$60-90^{\circ} \mathrm{N}$} & 2000 & $-18.20(-5.41)$ & $-26.17(-7.91)$ & $-32.57(-10.00)$ \\
\hline & & 2040 & $-12.30(-3.48)$ & $-20.25(-5.82)$ & $-26.65(-7.77)$ \\
\hline & \multirow[t]{2}{*}{$30-60^{\circ} \mathrm{N}$} & 2000 & $-6.64(-2.13)$ & $-11.06(-3.58)$ & $-14.90(-4.88)$ \\
\hline & & 2040 & $-2.15(-0.66)$ & $-6.27(-1.96)$ & $-9.84(-3.11)$ \\
\hline & \multirow[t]{2}{*}{$30-60^{\circ} \mathrm{S}$} & 2000 & $-8.67(-2.80)$ & $-13.17(-4.33)$ & $-16.98(-5.70)$ \\
\hline & & 2040 & $-1.90(-0.58)$ & $-5.59(-1.75)$ & $-8.93(-2.84)$ \\
\hline & \multirow[t]{2}{*}{$60-90^{\circ} \mathrm{S}$} & 2000 & $-15.93(-5.78)$ & $-21.87(-8.21)$ & $-26.35(-10.23)$ \\
\hline & & 2040 & $-7.08(-2.32)$ & $-12.23(-4.11)$ & $-16.44(-5.67)$ \\
\hline \multirow[t]{8}{*}{ ASO } & \multirow[t]{2}{*}{$60-90^{\circ} \mathrm{N}$} & 2000 & $-8.16(-2.58)$ & $-15.11(-4.86)$ & $-20.79(-6.79)$ \\
\hline & & 2040 & $-1.53(-0.47)$ & $-7.69(-2.38)$ & $-12.66(-3.97)$ \\
\hline & \multirow[t]{2}{*}{$30-60^{\circ} \mathrm{N}$} & 2000 & $-3.20(-1.05)$ & $-7.26(-2.42)$ & $-10.63(-3.59)$ \\
\hline & & 2040 & $2.03(0.65)$ & $-1.56(-0.50)$ & $-4.53(-1.48)$ \\
\hline & \multirow[t]{2}{*}{$30-60^{\circ} \mathrm{S}$} & 2000 & $-13.63(-4.46)$ & $-16.62(-5.58)$ & $-18.75(-6.44)$ \\
\hline & & 2040 & $-7.71(-2.37)$ & $-11.03(-3.47)$ & $-13.59(-4.38)$ \\
\hline & \multirow[t]{2}{*}{$60-90^{\circ} \mathrm{S}$} & 2000 & $-26.04(-14.62)$ & $-23.75(-14.39)$ & $-21.24(-13.80)$ \\
\hline & & 2040 & $-33.27(-13.44)$ & $-33.06(-14.42)$ & $-31.89(-15.02)$ \\
\hline \multirow[t]{8}{*}{ NDJ } & \multirow[t]{2}{*}{$60-90^{\circ} \mathrm{N}$} & 2000 & $-6.06(-1.65)$ & $-11.14(-3.07)$ & $-15.46(-4.31)$ \\
\hline & & 2040 & $0.42(0.11)$ & $-3.78(-0.97)$ & $-7.46(-1.93)$ \\
\hline & \multirow[t]{2}{*}{$30-60^{\circ} \mathrm{N}$} & 2000 & $-2.78(-0.85)$ & $-6.01(-1.85)$ & $-8.78(-2.73)$ \\
\hline & & 2040 & $1.91(0.56)$ & $-0.79(-0.23)$ & $-3.17(-0.94)$ \\
\hline & \multirow[t]{2}{*}{$30-60^{\circ} \mathrm{S}$} & 2000 & $-7.81(-2.70)$ & $-9.26(-3.26)$ & $-10.27(-3.66)$ \\
\hline & & 2040 & $-6.33(-2.07)$ & $-7.98(-2.65)$ & $-9.02(-3.05)$ \\
\hline & \multirow[t]{2}{*}{$60-90^{\circ} \mathrm{S}$} & 2000 & $-14.59(-6.50)$ & $-12.78(-5.85)$ & $-11.03(-5.18)$ \\
\hline & & 2040 & $-25.60(-9.51)$ & $-23.59(-9.15)$ & $-21.02(-8.49)$ \\
\hline
\end{tabular}

for the calculation of the UV index). The weighted spectrum, termed $\mathrm{UV}_{\mathrm{ERY}}$, has units of $\mathrm{kJ} \mathrm{m}^{-2} \mathrm{day}^{-1}$.

In Fig. 3, we illustrate the difference of annual averaged $\mathrm{UV}_{\mathrm{ERY}}$ resulting only from changes of column ozone due to geo-engineering for different levels of $\mathrm{Br}_{\mathrm{y}}^{\mathrm{VSL}}$ and $\mathrm{Cl}_{\mathrm{y}}^{\mathrm{VSL}}$. Seasonal and local changes in $\mathrm{UV}_{\mathrm{ERY}}$ are much larger, for instance in spring at the location of the polar vortex. Any effects of changing cloudiness are not considered, as the re- sponse of cloudiness to geo-engineering cannot be forecast reliably. The impact on $\mathrm{UV}_{\mathrm{ERY}}$, due to scattering by stratospheric sulfate aerosols is discussed further below.

The inclusion of additional levels of enhanced halogens in the stratosphere results in a decrease of column ozone and an increase of $\mathrm{UV}_{\mathrm{ERY}}$. In case of $\mathrm{VSL}=0$ the impact of geoengineering on $U V_{E R Y}$ is between $\pm 2 \%$ in low and midlatitudes and slightly negative equatorward of $\pm 45^{\circ}$ for the 


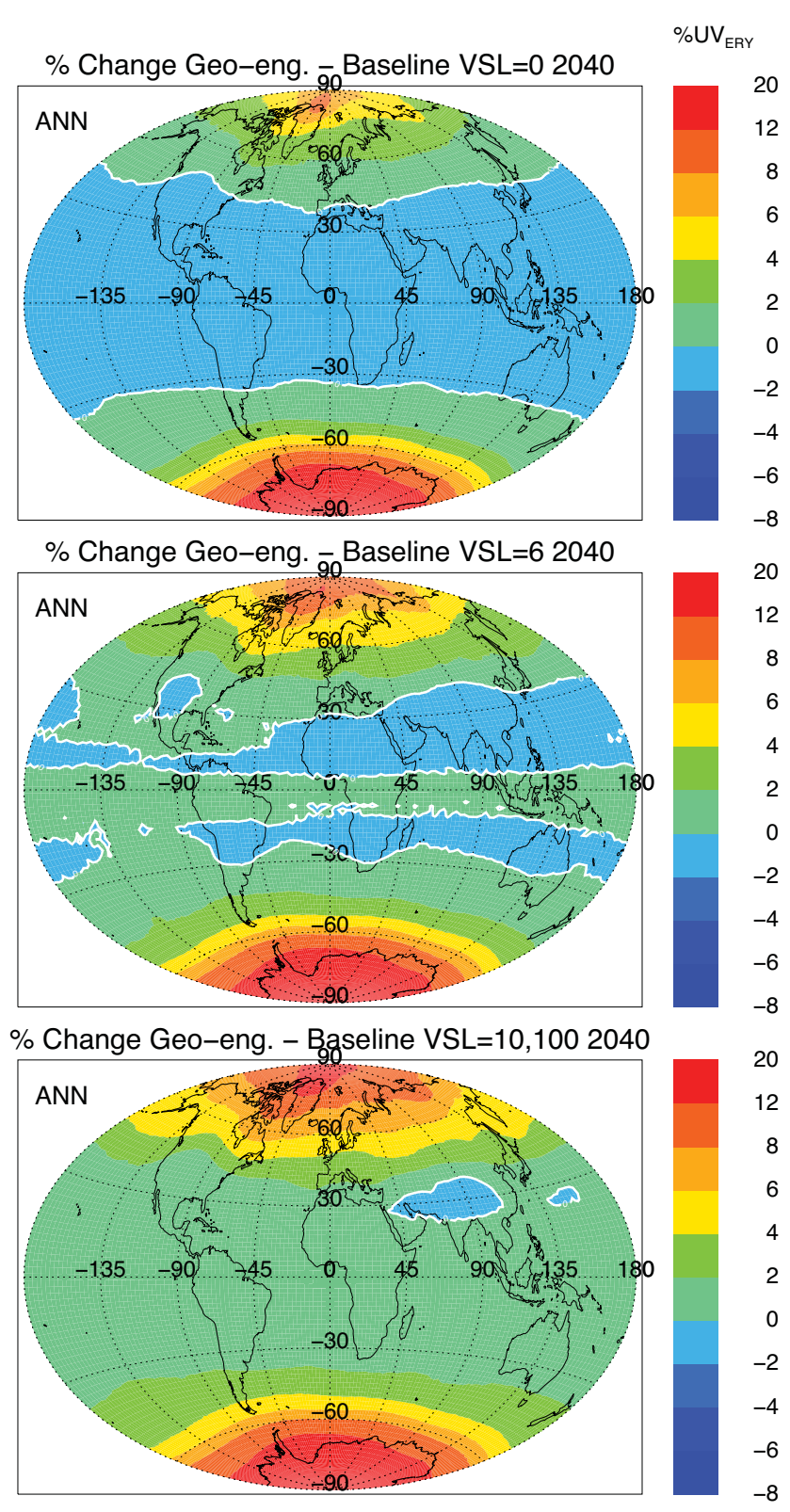

Fig. 3. Relative changes of UV radiation weighted for human erythema (skin-reddening) due to geo-engineering, for projected chemical conditions in year 2040. Changes are the result of differences in column ozone between the geo-engineering and the baseline simulation. The additional amount of stratospheric bromine from VSL halogens is assumed to be zero (top) and $\mathrm{Br}_{\mathrm{y}}^{\mathrm{VSL}}=6 \mathrm{ppt}$ (middle) and $\mathrm{Br}_{\mathrm{y}}^{\mathrm{VSL}}=10 \mathrm{ppt}, \mathrm{Cl}_{\mathrm{y}}^{\mathrm{VSL}}=100 \mathrm{ppt}$ (bottom). The white line represents the zero contour.

year 2040 (Fig. 3, top). On the other hand, UV $\mathrm{ERY}_{\text {increases }}$ towards the poles by up to $7 \%$ in northern high latitudes and by more than $10 \%$ for southern high latitudes. For the $\mathrm{Br}_{\mathrm{y}}^{\mathrm{VSL}}=6$ ppt simulation (Fig. 3, middle), $\mathrm{UV}_{\text {ERY increases }}$ by up to $4 \%$ between 45 and $60^{\circ} \mathrm{N}$ for 2040 compared to the baseline simulation. Further, reduced column ozone in the tropics assuming $\mathrm{Br}_{\mathrm{y}}^{\mathrm{VSL}}=10 \mathrm{ppt}, \mathrm{Cl}_{\mathrm{y}}^{\mathrm{VSL}}=100$ ppt changes the sign of $U_{\mathrm{ERY}}$ from a slight decrease of $\approx 0-2 \%$ for $\mathrm{VSL}=0$ to an increase of $\approx 0-2 \%$ (Fig. 3 , bottom). For the $\mathrm{VSL}=10+100$ case, we further find a significant increase of $\mathrm{UV}_{\mathrm{ERY}}$ in mid- and high latitudes reaching up to $6 \%$ and over $12 \%$, respectively, compared to the baseline simulation.

We now quantify the impact of increased scattering by stratospheric sulfate aerosols on $\mathrm{UV}_{\mathrm{ERY}}$ (see Fig. 4). An increase in optical depth increases the radiation path lengths and therefore the diffuse-to-direct ratio of surface UV. The aerosol optical depth for baseline and geo-engineering simulations is calculated directly from the SAD of the different model simulations, using the TUV model. We use an extinction efficiency of $\sim 1.9$ calculated from Mie scattering over 300 to $320 \mathrm{~nm}$ assuming an effective radius of 0.43 microns (consistent with what was assumed in Rasch et al. (2008b)). Depending on season and latitude, UV changes due to geoengineering are reduced by a maximum of $2-3 \%$ (Fig. 4 , dotted lines). At high latitudes for seasons when solar zenith angle is large, increased scattering results in a slight increase in $\mathrm{UV}_{\mathrm{ERY}}$.

The combined effect on $U_{\text {ERY }}$ due to changes in column ozone and aerosol scattering induced by geo-engineering is shown by the solid lines in Fig. 4. The left panel shows results for the $\mathrm{Br}_{\mathrm{y}}^{\mathrm{VSL}}=0$ case and the right panel for the $\mathrm{Br}_{\mathrm{y}}^{\mathrm{VSL}}=10 \mathrm{ppt}, \mathrm{Cl}_{\mathrm{y}}^{\mathrm{VSL}}=100 \mathrm{ppt}$ simulation. For low latitudes changes in $U V_{E R Y}$ are negative for all cases considered. The most obvious difference between $\mathrm{VSL}=0$ and $\mathrm{VSL}=10+100$ is found for spring and fall in mid- and high latitudes. For example, for ASO in northern mid-latitudes and for FMA in southern mid-latitudes, the impact of geoengineering on $U V_{E R Y}$ has increased from near zero for $\mathrm{VLS}=0$ to $\mathrm{a} \approx 5 \%$ increase for VLS $=10+100$. The relative impact of aerosol scattering is small in winter and spring high latitudes, where changes in ozone control the changes in $\mathrm{UV}_{\mathrm{ERY}}$ as a result of geo-engineering.

For comparison, the decline in TOMS ozone column data between the decades 1979-1989 and 1990-2000 resulted in an increase of 2 to $7 \%$ for $\mathrm{UV}_{\mathrm{ERY}}$ between 30 and $60^{\circ} \mathrm{N}$ and an increase of more than $10 \%$ in southern high latitudes for clear sky conditions (Lee-Taylor and Madronich, 2007; McPeters et al., 1996; Herman, 2010). These changes were caused by the increase of CFCs in the stratosphere. When VSL halogens are consider in the model, geo-engineering might lead to a similar impact on column ozone and thus $\mathrm{UV}_{\mathrm{ERY}}$ in 2040.

\section{Conclusions}

Prior studies have shown that enhanced sulfate aerosols in the stratosphere from geo-engineering will result in a significant decrease of column ozone for present day (Heckendorn et al., 2009) and future conditions (Tilmes et al., 2008, 2009). Previous model studies only considered long-lived halogen 

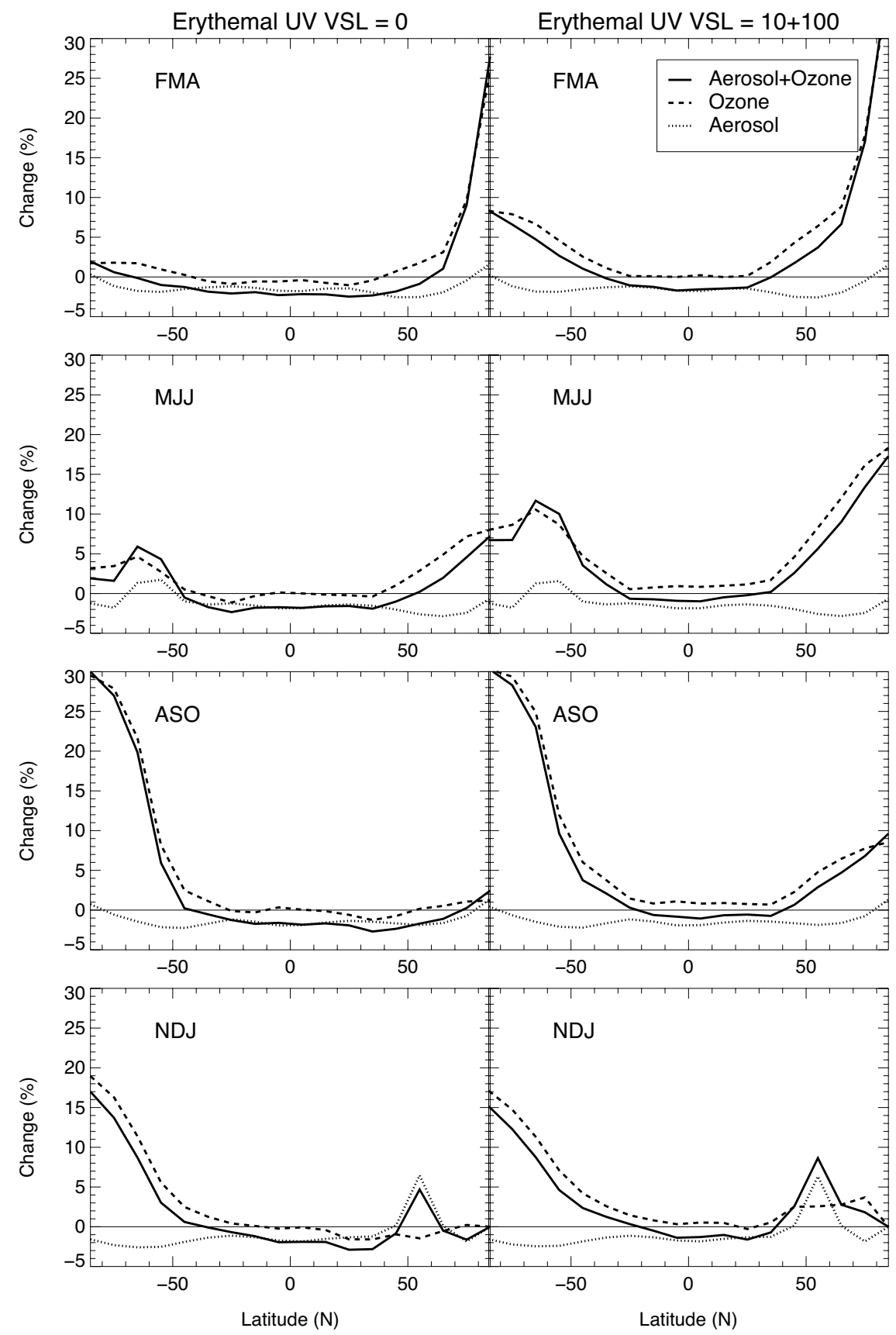

Fig. 4. Changes in $U_{\text {ERY }}$ as a result of geo-engineering, assuming volcanic-sized aerosols for the year 2040, based on changes of column ozone only (dashed lines), changes due to the enhanced volcanic-sized aerosol scattering only (dotted lines), and, consideration of both column ozone changes and enhanced aerosol scattering (solid). Results are shown for four seasons, noontime conditions averaged over 10 degrees latitude bands. We consider simulations with two different amounts of VSL halogen species in the stratosphere (VSL $=0$ : left column, $\mathrm{Br}_{\mathrm{y}}^{\mathrm{VSL}}=10 \mathrm{ppt}$ and $\mathrm{Cl}_{\mathrm{y}}^{\mathrm{VSL}}=100 \mathrm{ppt}$ : right column).

sources. We show that the consideration of VSL halogen source species, in a geo-engineering calculation focused on the year 2040, leads to larger decreases in column ozone for nearly all seasons, at nearly all latitudes. The largest relative impact of VSL halogen sources is found for northern midand high latitudes in summer, where the additional $\mathrm{Br}_{\mathrm{y}}$ and
$\mathrm{Cl}_{\mathrm{y}}$ from VSL sources leads to column ozone decreases of up to $4 \%$ compared to a geo-engineering simulation that neglects VSL halogens.

Changes in column ozone and stratospheric aerosol content due to geo-engineering will impact erythemal UV radiation reaching the surface $\left(\mathrm{UV}_{\mathrm{ERY}}\right)$. A calculation considering 
the upper limit of additional $\mathrm{Br}_{\mathrm{y}}$ and $\mathrm{Cl}_{\mathrm{y}}$ from VSL source species, and only the effect of ozone on $U_{\mathrm{ERY}}$, results in a $12 \%$ annual increase in $\mathrm{UV}_{\mathrm{ERY}}$ in the SH high latitudes and up to $6 \%$ in $\mathrm{NH}$ high latitudes due to geo-engineering. Considering the impact of scattering from geo-engineering aerosols we find a reduction of $\mathrm{UV}_{\mathrm{ERY}}$ by about 2 to $3 \%$ for most latitudes and seasons. Considering the combinded effects on $\mathrm{UV}_{\mathrm{ERY}}$ of ozone and aerosol scattering underlines the importance of VSL halogen sources: for spring and fall in mid- and high latitudes, the effect of geo-engineering on $\mathrm{UV}_{\mathrm{ERY}}$ switches from neutral (a balance between the increase due to ozone depletion and a decrease due to aerosol scattering) to a rise of $\approx 5 \%$. In this case, the $\mathrm{UV}_{\mathrm{ERY}}$ increase due to ozone depletion driven by VSL halogens exceeds $U_{\text {ERY }}$ decrease due to aerosol scattering. Upon consideration of VSL halogens, we find that geo-engineering due to sulfate injection could result, for year 2040, in an increase of $U_{\mathrm{ERY}}$ comparable to levels observed during the 1979 to 2000 time period, due to peak levels of CFCs and other ozone depleting substances.

We have investigated one specific meteorological situation for all simulations, which aids the interpretation of the model output, but also means interannual temperature variations are not considered. Such variations can lead to large differences of chemical ozone loss in winter and spring at northern high latitudes. The impact of VSL halogens would be smaller for a warmer Arctic winter than considered here and larger for colder winters. Further, the long-lasting SH polar vortex in our simulation likely results in an overestimation of the annual column ozone reduction in southern high latitudes. For the other latitudes, however, precise temperature is likely to be less important. We have also not considered changes in stratospheric dynamics induced by the VSL halogen driven loss of ozone, which could be important and should be quantified in future studies.

Simplified assumptions were also made regarding the location and size distribution of the geo-engineered stratospheric aerosol layer. Large uncertainties exist on these matters, which strongly depend on the emission strategy and composition of the injected particles (Heckendorn et al., 2009; Pierce et al., 2010; Niemeier et al., 2010). Smaller particles enhance the rate of heterogeneous reactions and therefore amplify ozone-destroying cycles. Larger particles experience faster gravitational settling and may result in a heating of the tropical tropopause, driving strong reduction of column ozone (Heckendorn et al., 2009). Finally, VSL halogen species have an impact on the tropospheric ozone budget (Saiz-Lopez et al., 2012), which we have also not considered.

In summary, this study reveals the importance of considering $\mathrm{Br}_{\mathrm{y}}^{\mathrm{VSL}}$ when quantifying the impact of geo-engineering on ozone and surface UV, which is one example that stresses the need for a deeper understanding of atmospheric processes, should geo-engineeing be considered to counteract climate change.
Supplementary material related to this article is available online at: http://www.atmos-chem-phys.net/12/ 10945/2012/acp-12-10945-2012-supplement.pdf.

Acknowledgements. We thank the GOME satellite team for providing high quality data of BrO. MERRA data used in this study have been provided by the Global Modeling and Assimilation Office (GMAO) at NASA Goddard Space Flight Center through the NASA GES DISC online archive. The National Center for Atmospheric Research is funded by the National Science Foundation. Work at UMd was supported by the NASA ACMAP and Aura programs.

Edited by: M. Dameris

\section{References}

Chance, K.: Analysis of BrO measurements from the Global Ozone Monitoring Experiment, Geophys. Res. Lett., 25, 3335-3338, doi:10.1029/98GL52359, 1998.

Choi, S., Wang, Y., Salawitch, R. J., Canty, T., Joiner, J., Zeng, T., Kurosu, T. P., Chance, K., Richter, A., Huey, L. G., Liao, J., Neuman, J. A., Nowak, J. B., Dibb, J. E., Weinheimer, A. J., Diskin, G., Ryerson, T. B., da Silva, A., Curry, J., Kinnison, D., Tilmes, S., and Levelt, P. F.: Analysis of satellite-derived Arctic tropospheric BrO columns in conjunction with aircraft measurements during ARCTAS and ARCPAC, Atmos. Chem. Phys., 12, 12551285, doi:10.5194/acp-12-1255-2012, 2012.

Crutzen, P. J.: Albedo enhancements by stratospheric sulfur injections: a contribution to resolve a policy dilemma? An Editorial Essay, Clim. Change, 77, 211-219, 2006.

Dlugokencky, E. J., Duttoni, E. G., Novelli, P. C., Tans, P. P., Masarie, K. A., Lantz, K. O., and Madronich, S.: Changes in $\mathrm{CH}_{4}$ and $\mathrm{CO}$ growth rates after the eruption of Mt. Pinatubo and their link with changes in tropical tropospheric UV flux, Geophys. Res. Lett., 23, 2761-2764, doi:10.1029/96GL02638, 1996.

Eyring, V., Butchart, N., Waugh, D. W., Akiyoshi, H., Austin, J., Bekki, S., Bodeker, G. E., Boville, B. A., Brühl, C., Chipperfield, M. P., Cordero, E., Dameris, M., Deushi, M., Fioletov, V. E., Frith, S. M., Garcia, R. R., Gettelman, A., Giorgetta, M. A., Grewe, V., Jourdain, L., Kinnison, D. E., Mancini, E., Manzini, E., Marchand, M., Marsh, D. R., Nagashima, T., Nielsen, E., Newman, P. A., Pawson, S., Pitari, G., Plummer, D. A., Rozanov, E., Schraner, M., Shepherd, T. G., Shibata, K., Stolarski, R. S., Struthers, H., Tian, W., and Yoshiki, M.: Assessment of temperature, trace species and ozone in chemistryclimate simulations of the recent past, J. Geophys. Res., 111, D22308, doi:10.1029/2006JD007327, 2006.

Eyring, V., Shepherd, T. G., and Waugh, D. W., eds.: SPARC Report on the Evaluation of Chemistry-Climate Models, SPARC Report No. 5, WCRP-132, WMO/TD-No.1526, 2010.

Fahey, D. W., Kawa, S. R., Woodbridge, E. L., Tin, P., Wilson, J. C., Jonsson, H. H., Dye, J. E., Baumgardner, D., Borrmann, S., and Toohey, D. W.: In situ measurements constraining the role of sulphate aerosols in mid-latitude ozone depletion, Nature, 363, 509-514, 1993. 
Feng, W., Chipperfield, M. P., Dorf, M., Pfeilsticker, K., and Ricaud, P.: Mid-latitude ozone changes: studies with a 3-D CTM forced by ERA-40 analyses, Atmos. Chem. Phys., 7, 2357-2369, doi:10.5194/acp-7-2357-2007, 2007.

Garcia, R. R., Marsh, D. R., Kinnison, D. E., Boville, B. A., and Sassi, F.: Simulation of secular trends in the middle atmosphere, 1950-2003, J. Geophys. Res., 112, D09301, doi:10.1029/2006JD007485, 2007.

Heckendorn, P., Weisenstein, D., Fueglistaler, S., Luo, B., Rozanov, E., Schraner, M., Thomason, L., and Peter, T.: The impact of geoengineering aerosols on stratospheric temperature and ozone, Environ. Res. Lett., 4, 045108, doi:10.1088/1748-9326/4/4/045108, 2009.

Herman, J. R.: Global increase in UV irradiance during the past 30 years (1979-2008) estimated from satellite data, J. Geophys. Res., 115, D04203, doi:10.1029/2009JD012219, 2010.

Hossaini, R., Chipperfield, M. P., Dhomse, S., Ordonez, C., Saiz-Lopez, A., Abraham, N. L., Archibald, A., Braesicke, P., Telford, P. J., Warwick, N. J., Yang, X., and Pyle, J.: Modelling future changes to the stratospheric source gas injection of biogenic bromocarbons, Geophys. Res. Lett., 39, L20813, doi:10.1029/2012GL053401, 2012.

Kinnison, D. E., Brasseur, G. P., Walters, S., Garcia, R. R., Marsch, D. A., Sassi, F., Boville, B. A., Harvey, V. L., Randall, C. E., Emmons, L., Lamarque, J. F., Hess, P., Orlando, J. J., Tie, X. X., Randel, W., Pan, L. L., Gettelman, A., Granier, C., Diehl, T., Niemaier, U., and Simmons, A. J.: Sensitivity of chemical tracers to meteorological parameters in the MOZART3 chemical transport model, J. Geophys. Res., 112, D20302, doi:10.1029/2006JD007879, 2007.

Lee-Taylor, J. and Madronich, S.: Climatology of UV-A, UV-B, and Erythemal Radiation at the Earth's Surface, 1979-2000, NCAR Technical Note TN-474-STR, 2007.

Lee-Taylor, J., Madronich, S., Mayer, B., and Fischer, C.: A Climatology of UV Radiation, 1979-2000, 65S-65N, in: UV Radiation in: Global Climate Change: Measurements, Modeling and Effects on Ecosystems, edited by: Gao, W., Schmoldt, D., and Slusser, J., 1-20, Springer-Verlag, Heidelberg, and Tsinghua University Press, Beijing, 2010.

Madronich, S. and Flocke, S.: Theoretical estimation of biologically effective UV radiation at the Earth's surface, in: Solar Ultraviolet Radiation - Modeling, Measurements and Effects, edited by: Zerefos, vol. 152, NATO ASI Series, Springer-Verlag, Berlin, 1997.

McKinlay, A. F. and Diffey, B. L.: A reference action spectrum for ultraviolet induced erythema in human skin, in: Human Exposure to Ultraviolet Radiation: Risks and Regulations, edited by: Passchier, W. R. and Bosnjakovic, B. F. M., 83-87, Elsevier, Amsterdam, 1987.

McPeters, R. D., Hollandsworth, S. M., Flynn, L. E., Herman, J. R., and Seftor, C. J.: Long-term ozone trends derived from 16-year combined Nimbus 7/Meteor 3 TOMS Version 7 record, Geophys. Res. Lett., 23, 3699-3702, doi:10.1029/96GL03540, 1996.

Mercado, L. M., Bellouin, N., Sitch, S., Boucher, O., Huntingford, C., Wild, M., and Cox, P. M.: Impact of changes in diffuse radiation on the global land carbon sink, Nature, 458, 189-194, doi:10.1038/nature07949, 2009.

Micheletti, M. I., Piacentini, R. D., and Madronich, S.: Sensitivity of Biologically Active UV Radiation to Stratospheric Ozone
Changes: Effects of Action Spectrum Shape and Wavelength Range, Photochemistry and Photobiology, 78, 456-461, 2003.

Niemeier, U., Schmidt, H., and Timmreck, C.: The dependency of geoengineered sulfate aerosol on the emission strategy, Atmos. Sci. Lett., 12, 189-194, doi:10.1002/asl.304, 2010.

Oman, L., Plummer, D. A., Waugh, D. W., Austin, J., Scinocca, J. F., Douglass, A. R., Salawitch, R. J., Canty, T., Akiyoshi, H., Bekki, S., Braesicke, P., Butchart, N., Chipperfield, M. P., Cugnet, D., Dhomse, S., Eyring, V., Frith, S., Hardiman, S. C., Kinnison, D. E., Lamarque, J.-F., Mancini, E., Marchand, M., Michou, M., Morgenstern, O., Nakamura, T., Nielsen, J. E., Olivíe, D.,. Pitari, G, Pyle, J., Rozanov, E., Shepherd, T. G., Shibata, K., Stolarski, R. S., Teyssedre, H., Tian, W., Yamashita, Y., and Ziemke, J. R.: Multimodel assessment of the factors driving stratospheric ozone evolution over the 21 st century, J. Geophys. Res., 115, D24306, doi:10.1029/2010JD014362, 2010.

Pierce, J., Weisenstein, D., and Keith, D.: Efficient formation of stratospheric aerosol for geoengineering through emission of lowvolatility vapours in an aircraft plume, Geophysical Research Abstracts, 12, 2010.

Portmann, R. W., Solomon, S., Garcia, R. R., Thomason, L. W., Poole, L. R., and McCormick, M. P.: Role of aerosol variations in anthropogenic ozone depletion in the polar regions, J. Geophys. Res., 101, 22991-23006, 1996.

Quack, B. and Wallace, D. R.: Air-sea flux of bromoform: Controls, rates, and implications, Global Biogeochem. Cy., 17, 1023, doi:10.1029/2002GB001890, 2003.

Rasch, P. J., Tilmes, S., Turco, R. P., Robock, A., Oman, L., and Chen, C.-C.: An overview of geoengineering of climate using stratospheric sulphate aerosols, Proc. R. Soc. London A, 366, 4007-4037, doi:10.1098/rsta.2008.0131, 2008a.

Rasch, R. J., J., C. P., and Coleman, D. B.: Exploring the geoengineering of climate using stratospheric sulfate aerosols: The role of particle size, Geophys. Res. Lett., 35, L02809, doi:10.1029/2007GL032179, 2008b.

Robock, A., Oman, L., and Stenchikov, G.: Regional climate response to geoengineering with tropical and Arctic $\mathrm{SO}_{2}$ injection, J. Geophys. Res., 113, D16101, doi:10.1029/2008JD010050, 2008.

Saiz-Lopez, A., Lamarque, J.-F., Kinnison, D. E., Tilmes, S., Ordóñez, C., Orlando, J. J., Conley, A. J., Plane, J. M. C., Mahajan, A. S., Sousa Santos, G., Atlas, E. L., Blake, D. R., Sander, S. P., Schauffler, S., Thompson, A. M., and Brasseur, G.: Estimating the climate significance of halogen-driven ozone loss in the tropical marine troposphere, Atmos. Chem. Phys., 12, 3939-3949, doi:10.5194/acp-12-3939-2012, 2012.

Salawitch, R. J., Weisenstein, D. K., Kovalenko, L. J., Sioris, C. E., Wennberg, P. O., Chance, K., Ko, M. K. W., and McLinden, C. A.: Sensitivity of ozone to bromine in the lower stratosphere, Geophys. Res. Lett., 32, L05811, doi:10.1029/2004GL021504, 2005.

Soden, B., Wetherald, R., Stenchikov, G., and Robock, A.: Global cooling after the eruption of Mount Pinatubo: A test of climate feedback by water vapor, Science, 296, 5568, doi:10.1126/science.296.5568.727, 2002.

Solomon, S., Portmann, R., Garcia, R. R., Thomason, L., Poole, L. R., and McCormick, M. P.: The role of aerosol variations in anthropogenic ozone depletion at northern midlatitudes, J. Geophys. Res., 101, 6713-6727, 1996. 
Solomon, S., Qin, D., Manning, M., Marquis, M., Averyt, K., Tignor, M. M. B., Miller, H. L., and Chen, Z., eds.: Climate Change 2007: The Physical Science Basis. Contribution of Working Group I to the Fourth Assessment Report of the Intergovernmental Panel on Climate Change, Cambridge University Press, Cambridge, UK and New York, NY, USA, 2007.

Stenchikov, G. L., Robock, A., Ramaswamy, V., Schwarzkopf, M. D., Hamilton, K., and Ramachandran, S.: Oscillation response to the 1991 Mount Pinatubo eruption: Effects of volcanic aerosols and ozone depetion, J. Geophys. Res., 107, 4803, doi:10.1029/2002JD002090, 2002.

Tabazadeh, A., Drdla, K., Schoeberl, M. R., Hamill, P., and Toon, O. B.: Arctic "ozone hole" in a cold volcanic stratosphere, P. Natl. Acad. Sci., 99, 2609-2612, 2002.

Tilmes, S., Kinnison, D., Müller, R., Sassi, F., Marsh, D., Boville, B., and Garcia, R.: Evaluation of heterogeneous processes in the polar lower stratosphere in the Whole Atmosphere Community Climate Model, J. Geophys. Res., 112, D24301, doi:10.1029/2006JD008334, 2007.

Tilmes, S., Müller, R., and Salawitch, R. J.: The sensitivity of polar ozone depletion to proposed geoengineering schemes, Science, 320, 1201-1204, doi:10.1126/science.1153966, 2008.

Tilmes, S., Garcia, R. R., Kinnison, D. E., Gettelman, A., and Rasch, P. J.: Impact of geoengineered aerosols on the troposphere and stratosphere, J. Geophys. Res., 114, D12305, doi:10.1029/2008JD011420, 2009.
Trenberth, K. E. and Dai, A.: Effects of Mount Pinatubo volcanic eruption on the hydrological cycle as an ana$\log$ of geoengineering, Geophys. Res. Lett., 34, L15702, doi:10.1029/2007GL030524, 2007.

UNEP: United Nations Environment Programme and Environmental Effects Assessment Panel. Environmental effects of ozone depletion and its interactions with climate change: Progress report, 2004, Photochem. Photobiol. Sci., 4, 177-184, doi:10.1039/b418650h, 2005.

Wennberg, P. O., Cohen, R. C., Stimpfle, R. M., Fahey, D. W., Webster, C. R., Salawitch, R. J., Proffitt, M. H., Chan, K. R., Anderson, J. G., and Wofsy, S. C.: The removal of lower stratospheric ozone by free radical catalysis: In situ measurements of $\mathrm{OH}$, $\mathrm{HO}_{2}, \mathrm{NO}, \mathrm{NO}_{2}, \mathrm{ClO}$, and BrO, Science, 266, 398-404, 1994.

Wigley, T. M.: A combined mitigation/geoengineering approach to climate stabilization, Science, 314, 452-454, 2006.

WMO: Scientific assessment of ozone depletion: 2010, Global Ozone Research and Monitoring Project-Report No. 51, Geneva, Switzerland, 2010.

Zeng, J., McKenzie, R., Stamnes, K., Wineland, M., and Rosen, J.: Measured UV spectra compared with discrete ordinate method simulations, J. Geophys. Res., 99, p. 23019 , doi:10.1029/94JD02145, 1994. 